\title{
From the Streets to the Courtroom: The Legacies of Quebec's anti-SLAPP Movement
}

\author{
Normand Landry
}

Years of social mobilization and sustained political lobbying led to the recent adoption of anti-SLAPP legislation in Quebec. While this achievement was largely seen as a victory by the organizations that led the campaign towards the enactment of anti-SLAPP measures, many questions remain about the actual level of protection offered by the new law to citizens of the province. This article aims to address these questions and will be divided in three parts. The first section will briefly contextualize Quebec's new legislation within the larger Canadian context. The second section will explore the social and political processes that led to the enactment of the legislation. Finally, the provisions of Bill 9 will be examined in order to determine whether it provides an appropriate response to SLAPP suits.

\section{Introduction}

On June 3, 2009, the Quebec National Assembly adopted Bill 9, 'An Act to amend the Code of Civil Procedure to prevent improper use of the courts and promote freedom of expression and citizen participation in public debate'. This legislation was enacted as a response to rising concern raised by citizens, civil society organizations and political representatives over a practice labeled in the province as 'the legal gagging of citizen speech' and the growing phenomenon of strategic lawsuits against public participation (SLAPPs) in the province. SLAPP suits refer to the processes by which a public or private actor - usually (but not always) a corporation, a developer or a businessperson uses the legal system in order to suppress a political controversy relating to an issue of public interest, in an attempt to silence or intimidate political opponents, or to retaliate against adversaries. SLAPPs present themselves as common law prosecutions requiring the defendant to pay considerable monetary compensation to the plaintiff for damages allegedly caused when individuals or groups question, denounce or otherwise oppose the 
plaintiff's actions for their implications on the wider public interest. ${ }^{1}$ They typically invoke defamation (by far the most frequent actions in Quebec), conspiracy, interference with economic interests, interference with contractual relations, trespass, violation of private property or nuisance. $^{2}$

SLAPPs are depicted in the literature as an American phenomenon that exploded in 'epidemic' proportions in the US in the second half of the $20^{\text {th }}$ Century and which were later exported to a number of other Western countries. ${ }^{3}$ Mobilization by both citizens and committed lawyers has led to the enactment of anti-SLAPP legislation in twenty-eight American States so far. ${ }^{4}$ While citizens, lawyers, journalists and elected representatives have been raising concerns over the last fifteen years regarding SLAPP suits being exported to Canada, legislative attempts to counter the strategic use of the court system to silence political opponents has remained unsuccessful until recently. While anti-SLAPP bills have been presented and defeated (as private members' bills) in Nova Scotia and New-Brunswick, British-Columbia adopted the first Canadian anti-SLAPP legislation in April 2001 (only to repeal it a few months later). Quebec is presently the only Canadian province to have an anti-SLAPP law.

\section{Strategic Lawsuits Against Public Participation: Canada's Missed Opportunities}

SLAPPs first emerged in Canada as an issue of social and political concern in the early 1990s. ${ }^{5}$ According to Wells, the exportation of SLAPP suits from the United States to Canada during this period has been 'extremely prodigious'. ${ }^{6}$ Environmental controversies, land disputes and real estate debates taking place on the west coast and elsewhere in Canada sparked controversial lawsuits and became illustrative of a larger phenomenon of legal intimidation targeting politically active citizens. ${ }^{7}$ British Columbia was hit especially hard by this new phenomenon: most of the SLAPP suits documented in

\footnotetext{
${ }^{1}$ See P. Canan and G. W. Pring, 'Strategic Lawsuits Against Public Participation', 35(5) Social Problems (1988), 515.

${ }^{2}$ G. W. Pring and P. Canan, Getting Sued for Speaking Out (Temple University Press, 1996). Rodney Wilts and O. Brandes and B. Rogachevsky, The West Coast Environmental

Law SLAPP Handbook, West Coast Environmental Law (November 2002) available at

$<$ http://www.wcel.org/wcelpub/2002/13959.pdf $>$

3 . W. Pring and P. Canan, n.2 above. See also J. Wells, 'Exporting SLAPPs: International Use of the U.S. "SLAPP” to Suppress Dissent and Critical Speech', 12:2 Temporary International and Comparative Law Journal (1998), 457.

${ }^{4}$ For updates and information on the American States and Territories holding Anti-SLAPP Statutes, visit the California Anti-SLAPP Project (CASP) website at <http://www.casp.net $>$.

${ }^{5}$ See C. Tollefson, 'Strategic Lawsuits Against Public Participation: Developing a Canadian Response', 73:2 The Canadian Bar Review (1994), 207; S. Lott, Corporate Retaliation Against Consumers: The Status of Strategic Lawsuits Against Public Participation (SLAPPS) in Canada (Public Interest Advocacy Center (PIAC), September 2004), available at < http://www.piac.ca/files/slapps.pdf >; Macdonald et al., Les poursuites stratégiques contre la mobilisation publique - les poursuites - bâillons (SLAPP). (Ministère de la Justice du Québec, 2007), available at

$<$ http://www.justice.gouv.qc.ca/Francais/publications/rapports/pdf/slapp.pdfpdf $>$.

${ }^{6}$ J. Wells, n. 3 above, at 469.

${ }^{7}$ See, for example, MacMillan Bloedel Ltd. v. Galiano Island Trust Committee, [1995] B.C.J. No. 1763 (BCCA) (QL) (leave to appeal refused [1995] S.C.C.A. No. 439 (Q.L.)) and Fraser v. Saanich (District), [1999] B.C.J. 3100 (BCSC) (QL).
} 
Canada during the first half of the decade have been instigated in that province. ${ }^{8}$ Those who had experienced or witnessed these lawsuits spoke of the psychological trauma and financial disaster that resulted from being thrown into the judicial system; they requested that legislative provisions be adopted by provincial governments to discourage SLAPPs, protect citizen speech, and ensure the continuity of public participation.

National awareness of SLAPPs grew from a David versus Goliath case that acquired 'paradigmatic' status in Canada as the incarnation of a rising trend towards the legal intimidation and repression of political activists. ${ }^{9}$ In 1995, Daishowa Inc, a Canadian pulp and paper company held by Japanese interests, launched a multi-million dollar lawsuit against Friends of the Lubicon, a small, poorly funded Toronto-based non-profit organization, and three of its most active members. ${ }^{10}$ The lawsuit came as a response to a national and international boycott of the company's products organized under the leadership of Friends of the Lubicon ('Friends'). The boycott was aimed at pressuring Daishowa to stop its logging activities on territories considered by the Lubicons as their rightful traditional lands. In its suit, Daishowa claimed the following against the defendants:

... restraining unlawful interference with Daishowa's contractual and economic relationships through the use of unlawful means such as threats, intimidation and coercion, misinformation and defamatory statements and the threat of secondary picketing and secondary boycott of Daishowa's customers; restraining secondary picketing and unlawful secondary boycott of Daishowa's customers; and restraining the communication of untruthful and defamatory statements in the course of their unlawful secondary boycott of Daishowa's customers. ${ }^{11}$

The case was highly complex, took a constitutional turn, and lasted for years. In its 1998 ruling, the Ontario Court of Justice rejected the economic torts claimed by Daishowa, refused to restrain the picketing activities of Friends, and held part of the defamation argument presented by the company. ${ }^{12}$ Daishowa appealed the decision but later reached an out-of-court settlement with the defendants. ${ }^{13}$ This case has been documented extensively and was closely associated with SLAPP suits. ${ }^{14}$

\footnotetext{
${ }^{8}$ C. Tollefson, 'Strategic Lawsuits and Environmental Politics: Daishowa Inc. V Friends of the Lubicon.' 31:11 Journal of Canadian Studies, (1996), 119.

${ }^{9}$ Ibid.

${ }^{10}$ Daishowa Inc. v. Friends of the Lubicon [1998] O.J. No. 1429 (Ont. S.C.) (QL); C. Tollefson, 'Strategic Lawsuits Against Public Participation: Developing a Canadian Response', 73:2 The Canadian Bar Review (1994), 207;

${ }^{11}$ Daishowa Inc. v. Friends of the Lubicon, n.10 above.

12 The Court found that the accusation of 'genocide' made by Friends against Daishowa was defamatory. Friends also publicly stated in its campaign that Daishowa had agreed to halt its logging activities on Lubicon territory until the land rights were settled. This was found to be false. Finally, the Court found that 'Daishowa's complaint about the Friends' allegations concerning Daishowa's logging plans strikes' was 'trivial' and refused to label them as defamatory. Ibid.

${ }^{13}$ See the press release of the Friends of the Lubicon entitled 'As of May 4, 2000, the Daishowa v. Friends of the Lubicon Court Battle has Ended Signaling Closure in a Twelve Year Long Dispute Between Daishowa and the Lubicon Nation' (Toronto, 3 May 2000) available at $<\mathrm{http}: / /$ tao.ca/ fol/pa/forestp/daifolp/po000504.htm>

${ }^{14}$ See C. Tollefson, n. 5 above.
} 


\section{Past and Current Legislative Attempts}

The first anti-SLAPP bill considered by a Canadian legislative assembly was presented as a private members' bill in New Brunswick in 1997. The bill followed a lawsuit initiated a year earlier by a pulp company against students, members of First Nations, and a conservation group protesting the company's logging practices in a sensitive natural area of the province. ${ }^{15}$ The private bill - Bill 102, the Public Participation Act - was essentially designed to protect 'the right of citizens to participate freely in the process of the government' from civil actions 'brought primarily to chill citizen participation or otherwise to harass or intimidate citizens and citizens' organizations' ${ }^{16}$ The bill therefore created a 'right of participation'. It stated that:

Every person has a right to participate fully in the process of government including the right to petition and communicate with government, and the freedom of speech, association and demonstration on matters of public policy. ${ }^{17}$

Bill 102 proposed a number of measures in order to meet its goals. It first established a mechanism for quickly dismissing an action that contravened the right of participation of the defendant. It further obliged that the respondent to the motion to dismiss (the plaintiff) demonstrate the legitimate nature of its action to the court. Any failure to do so would have led to the dismissal of the action and to the reimbursement of the costs supported by the defendant in the preparation of its defense, including those for legal expertise and representation. Finally, the bill authorized defenders to claim damages from the plaintiff in conjunction with a motion instigated under the Act. Bill 102 never got further than first reading at the New Brunswick Legislative Assembly and died on the order paper a few years later.

A watershed moment happened in the Canadian anti-SLAPP landscape two years later at the opposite end of the country. On May 31, 1999, Justice Singh of the British Columbia Supreme Court gave a ruling that both qualified a particular case as a SLAPP and defined the very concept. For the first time, a Canadian court recognized the existence of a specific form of legal intimidation targeting politically active citizens and articulated a judgment based on this recognition. In his judgment, Justice Singh said:

A SLAPP suit is a claim for monetary damages against individuals who have dealt with a government body on an issue of public interest or concern. It is a meritless action filed by a plaintiff whose primary goal is not to win the case but rather to silence or intimidate citizens who have participated in proceedings regarding public policy or public decision making.

What the plaintiffs expect to receive they should clearly also expect to deliver. I find, therefore, finally, that this action not only contains an unreasonable claim, is meritless and devoid of any factual foundation, but also has been used as an attempt to stifle the democratic activities of the defendants, the

\footnotetext{
${ }^{15}$ See Lott, n. 5 above. See also E. May, 'SLAPPing the Citizenry', Rabble.ca (7 April 2004), available at $<\mathrm{http} / / / \mathrm{www}$.rabble.ca/news/slapping-citizenry>.

${ }^{16}$ Introductory Notes. Bill 102, The Public Participation Act. New Brunswick, $2^{\text {nd }}$ session, $53^{\text {rd }}$ Legislature, 1996-1997.

${ }_{17}^{17}$ Article 3: Right of Participation. Bill 102, The Public Participation Act. New Brunswick, $2^{\text {nd }}$ session, $53^{\text {rd }}$ Legislature, 1996-1997.
} 
neighbourhood residents. I find the plaintiffs' conduct reprehensible and deserving of censure by an award of special costs. ${ }^{18}$

This ruling fuelled public demand for the development of anti-SLAPP legislation in British Columbia and reinforced the position of those arguing for legislative action. Responding to popular pressure and lobbying, the provincial New Democratic Party government adopted Bill 10, The Protection of Public Participation Act in April 2001. British Columbia became the first Canadian province to adopt anti-SLAPP legislation. The purpose of the Protection of Public Participation Act was to:

(a) encourage public participation, and dissuade persons from bringing or maintaining proceedings or claims for an improper purpose, by providing:

i. an opportunity, at or before the trial of a proceeding, for a defendant to allege that, and for the court to consider whether, the proceeding or a claim within the proceeding is brought or maintained for an improper purpose,

ii. a means by which a proceeding or claim that is brought or maintained for an improper purpose can be summarily dismissed,

iii. a means by which persons who are subjected to a proceeding or a claim that is brought or maintained for an improper purpose may obtain reimbursement for all reasonable costs and expenses that they incur as a result,

iv. a means by which punitive or exemplary damages may be imposed in respect of a proceeding or claim that is brought or maintained for an improper purpose, and

v. protection from liability for defamation if the defamatory communication or conduct constitutes public participation.

(b) preserve the right of access to the courts for all proceedings and claims that are not brought or maintained for an improper purpose. ${ }^{19}$

According to the law, proceedings or claims brought before the court for an improper purpose would have 'no reasonable expectation of success'. An improper purpose included the following:

-to dissuade the defendant or other person from engaging in public participation,

- to divert the defendant's resources from public participation, or

- to penalize the defendant for engaging in public participation. ${ }^{20}$

British Columbia's new law had the potential of having a significant impact on other antiSLAPP legislation, both at the national and international levels, ${ }^{21}$ but it was short-lived. A newly elected liberal government repealed the law in August 2001, only a few months after its enactment by the Legislative Assembly of British Columbia, arguing that the "the law already protects the rights of people against frivolous and vexatious litigation through

${ }_{18}^{18}$ See Fraser v. Saanich (District), n. 7 above.

${ }^{19}$ The Protection of Public Participation Act. Section (2) (a). SBC 2001 Chapter 19 - Bill 10 [5th Sess, 36th Parl] (2001).

${ }^{20}$ Ibid., Section 2 (a) and (b).

${ }^{21}$ The Protection of Public Participation Act will influence similar legislative initiatives in Australia. Tasmania's 2005 anti-SLAPP bill illustrates a fascinating phenomenon of legislative mimicry and relies heavily both on the language and mechanisms developed in the British Columbia's legislation. See the Protection of Public Participation Bill 2005, Bill 14, Parliament of Tasmania (2005) at $<$ http://www.parliament.tas.gov.au/bills/Bills2005/pdf/14_of_2005.pdf > 
the Rules of the Supreme Court' and that the Act 'would have caused delays in the court system'.22

The act of repealing the Protection of Public Participation Act drew the consternation of both citizens and civil society organizations throughout the province and was characterized by many as moving away from principles of deliberative democracy. However, no other anti-SLAPP legislation has been presented in the province's Legislative Assembly since 2001. Yet British Columbia's legislation did have some impact and inspired a similar legislative initiative in Nova Scotia two years later. Again, a private bill was presented by a member of Parliament from the New Democratic Party to the legislature but it failed to become law. ${ }^{23}$ Nova Scotia's Bill, also entitled the Protection of Public Participation Act, had as its primary objectives 'to encourage public participation and dissuade persons from bringing or maintaining legal proceedings or claims for an improper purpose and to preserve access to the courts'. The bill was virtually identical to the British Columbia law and could even be considered as a legislative replica of it. The emulation continued in Ontario, where a private bill, again relying extensively over the British Columbia law, was presented in December $2008 .^{24}$ The bill did not go beyond first reading.

All and all, the failure to adopt and uphold anti-SLAPP legislation in New Brunswick, British Columbia and Nova Scotia is illustrative of the legal and political challenges surrounding legal intimidation and abuse of justice. Anti-SLAPP legislation invokes highly sensitive legal issues that are often controversial. ${ }^{25}$ In light of these difficulties, proponents of anti-SLAPP legislation have to convince their elected representatives of essentially three things:

1. the presence of the phenomenon in the jurisdiction (often illustrated by highprofile legal cases);

2. the gravity or seriousness of the situation and the necessity of acting legislatively on the issue; and,

3. the existence of clear, relatively easily enforceable legal remedies to the problem.

It will be demonstrated in the upcoming pages that activists and citizens from the province of Quebec successfully undertook these tasks and built social and political consensus required in order to mobilize the need to legislate on SLAPP suits.

\section{Suing Citizens; Building a Movement: the Social History of Quebec's Legislation}

\footnotetext{
${ }^{22}$ B.C. Ministry of Attorney General Response to Union of B.C. Municipalities 2001 Resolution, cited in Lott, 2004 (page number not specified).

${ }^{23}$ The bill was presented to the Nova Scotia Legislature by Howard Epstein for first reading on 23 October, 2003. It failed to get further at the parliament. Bill 25. [1st Sess, 59th General Assembly, 2003].

${ }^{24}$ Bill 138, An Act to Encourage Participation in Public Debate, and to Dissuade Persons from Bringing Legal Proceedings or Claims for an Improper Purpose. Ontario, $1^{\text {st }}$ session, 39 Legislature, 2008.

${ }^{25}$ The American experience is instructive on the matter. See J.W. Beatty, 'The Legal Literature on SLAPPs: A Look Behind the Smoke Nine Years After Professors Pring and Canan Yelled "Fire!", 9:85 University of Florida J. of Law and Public Policy, (1997), 88.
} 
Quebec's 2009 anti-SLAPP legislation was the result of a three-year process of social mobilization and consensus building throughout the province. It followed an initial phase where the issue was discovered - the hard way - and brought to the attention of citizens' groups. Individuals and organizations then acted on the issues and devoted themselves to building a sustained anti-SLAPP campaign and worked to establish social and political consensus over the need and relevance to adopt some kind of legislation on abusive lawsuits. These various steps will be described and discussed in this section.

\section{Discovering SLAPPs: the Crucial Role of Citoyens, Taisez-vous!}

As is often the case, public awareness over the threats of strategic lawsuits against public participation grew in Quebec during a high-profile legal case that infuriated segments of the population. The case suggested a broader concern in which the fundamental civic and political rights of the citizenry were made vulnerable.

In November 2005, a CAD \$5 million lawsuit was launched by American Iron and Metal Inc. (AIM) against two non-governmental environmental organizations, private citizens and a competitor, alleging that these parties conspired against it, attacked its reputation, and ultimately were responsible for financial losses suffered by the company. ${ }^{26}$ This lawsuit was instigated as a response to legal actions previously undertaken by the Association québécoise de lutte contre la pollution atmosphérique (AQLPA) and the Comité de restauration de la rivière Etchemin (CREE) against the corporation. These organizations feared that the construction of a car shredder plant on a former dumping site located near a sensitive natural area might jeopardize more than a decade of efforts to restore the Etchemin River and further pose a threat to the environmental safety of the region. They argued that AIM had not obtained the construction permit from the municipality, had not provided the Ministry of Sustainable Development, Environment and Parks with an environmental assessment (as requested by law) and had not produced a Request for Authorization prior the operation of the site. ${ }^{27}$ Representatives from the AQLPA and the CREE asked the Superior Court of Quebec for an injunction to stop the construction on the site until AIM complied with Quebec's environmental law. The injunction was granted in July 2005 and was renewed a fifteen times. ${ }^{28}$ It stopped the construction of the plant for months. AIM replied to the action undertaken by the AQLPA and the CREE with a multi-million dollar lawsuit. This legal action was understood by the two environmental organizations as a SLAPP suit. $^{29}$

\footnotetext{
${ }^{26}$ See AQLPA and CREE, 'Abuse of Process: A threat to Citizens' Participation Rights - Alarm Sounded by Quebec Environmentalists Who Were Subjected to Intimidation.' Canada NewsWire (23 March 2006).

${ }^{27}$ A. Bélisle, 'Injonction contre le projet de AIM-Québec à Lévis - La protection de l'environnement et l'application équitable de la loi: Les seuls objectifs des écologistes', Canada NewsWire (18 November 2005).

28 'La Cour Supérieure et la Cour d'Appel du Québec donnent raison à l'AQLPA et au CRRE - La Cour ordonne pour la deuxième fois à AIM de laisser les experts de l'AQLPA et du CRRE effectuer leurs vérifications.' Canada NewsWire (16 December 2005). See also 'Dossier AIM à Lévis - L'AQLPA et le CRRE remportent une nouvelle manche - La Cour supérieure ordonne à AIM de n'entreprendre aucun ouvrage sur le site', Canada NewsWire (7 April 2006).

${ }^{29}$ G. Bourgault-Côté, 'Bâillon sur un groupe écolo', Le Devoir (18 August 2006), at A1.
} 
Fearing for the survival of the organizations (as well as for the financial and psychological well-being of the individuals targeted by the lawsuits), members of the AQLPA and the CREE launched a public anti-SLAPPs campaign in October 2006 entitled 'Citoyens, taisez-vous!' (literally, Citizens, Be Quiet!). The campaign had three objectives:

- to finance the legal defense of the defendants, gather money, and avoid bankruptcy;

- to inform and educate the public over the threat of SLAPP suits; and

- finally (and foremost) to convince the government to adopt anti-SLAPP legislation based on the models already adopted in the US.

For months, dedicated activists reached and lobbied members of the provincial legislature, built a media campaign, and gathered support from civil society. When the campaign was launched in October 2006, more than fifty civil society organizations, including the three most powerful unions of the province and high-profile public personalities, were already endorsing its goals. The campaign also quickly received support from the major political parties of the province and was eagerly looking forward to the endorsement by the provincial government.

Citoyens, taisez-vous! also used innovative media strategies and innovative imagery to illustrate the 'gagging effect' of SLAPP suits over citizen speech. Groups and citizens gagged themselves in specific, evocative locations - whether at the National Assembly, the Superior Court or during press conferences - in order to attract media coverage, generate support for the establishment of anti-SLAPP legislation in Quebec, and communicate the social and political issues associated with abusive prosecution. The campaign attracted extensive media coverage and brought a number of other disturbing cases to the attention of the public and the legislature. ${ }^{30}$

The provincial Minister of Justice at the time took note of the growing social and political consensus requesting legislative action on SLAPP suits and announced in early October 2006 that he had mandated a committee of eminent legal experts to study the SLAPP

\footnotetext{
${ }^{30}$ Environmental groups and organizations were by far the hardest hit by prosecutions responding to citizen participation in Quebec. Most of these legal challenges opposed small, poorly funded organizations or individual citizens with companies or businesspeople. The following cases provide a good illustration of this argument. In May 2006, the spokesperson of a community-based group of citizens was sued for defamation. The claim against him was for CAD $\$ 700000$. The group was exasperated by the presence of strong and unpleasant odors in their neighborhood produced by a recycling plant. The spokesperson had previously qualified the odors as those of 'putrefaction of dead bodies.' See D. Bombardier, 'Fertival intente une poursuite de 700000 \$' La Tribune (17 May 2006).

In August 2006, two citizens were sued for defamation by the owners of a dump site for CAD $\$ 1.25$ million. The suit followed their political involvement in a local campaign that requested the authorities to close the site. The serious environmental hazards produced by the dumping site, as well as the owners' noncompliance with the environmental law led to the closure of the site in 2006. See D. Rogers, 'Cantley Residents Push Quebec to Clean Up Smelly, Bankrupt Dump' The Ottawa Citizen (7 August 2009). For a timeline of the event proceeding and following the lawsuit, see 'La SAGA du dépotoir de Cantley: Des nouvelles sur la poursuite de 1250000 \$ contre Serge Galipeau et Christine Landry’ Réseau Québécois des groups écologistes, at $<$ http://www.rqge.qc.ca/node/887 >
} 
situation in Quebec. This committee, headed by prominent law professor Roderick A. Macdonald, was to 'prepare a status report of current rules in Quebec, Canada and the United States on the balance between freedom of expression and the right to reputation, and between the right to address the courts and the reasonableness of action' (translation by the author). ${ }^{31}$ The committee was further charged to propose legislative solutions to the government in the event that it would find that measures had to be taken to protect the judicial system and citizens from abusive lawsuits.

The committee was given six months to accomplish its mandate and sent its report to the Minister of Justice on March 15, 2007. The report was made public a few months later and became both a fundamental tool for public education on SLAPPs, an instrument of political lobbying for those committed to the establishment of anti-SLAPP legislation, and the starting point from which the provincial government considered acting on the issue.

\section{Constructing SLAPPs: The Macdonald Report}

The 100-page Macdonald Report quickly became the cornerstone of political discussions over SLAPP suits in Quebec and remained an unavoidable reference document throughout the political and legislative processes leading to the enactment of Bill 9. The centrality of this report in the discussions around SLAPPs can be explained by a number of points. First, it had a strong pedagogical dimension and became an essential tool of social mobilization and awareness-building amongst citizens' groups and organizations. The report synthesized, translated and contextualized, in clear and accessible language, the existing socio-legal Anglo-Saxon literature on the subject. It also importantly identified SLAPPs as a complex and multi-faceted phenomenon and presented an analysis of the SLAPP phenomenon in Western countries with a focus on Australia, the United-States and English Canada. It addressed issues of diverging definitions, ${ }^{32}$ presented the social and legal dimensions of SLAPP suits in various judicial and constitutional settings, and finally contextualized the practice in the Quebec, including its social, political and judicial ramifications. It became a platform for popular education on SLAPPs and was used in various information sessions held by the Réseau Québécois des groups écologistes in which civil society organizations and citizens participated. Interestingly enough, the report defined SLAPP suits as:

1) lawsuits 2) undertaken against organizations or individuals 3 ) who are engaged in the public sphere and discussing issues of public interest, 4) aiming at limiting the scope of freedom of expression of these organizations or individuals and to neutralize their action 5) by using the courts to intimidate them, impoverish them, and deter them away from their public actions. ${ }^{33}$ (Translation by the author.)

\footnotetext{
${ }^{31}$ Danièle Montminy, 'Annexe 1 : Mandat confié au Comité par le ministère de la Justice', in Macdonald et al., Les poursuites stratégiques contre la mobilisation publique - les poursuites - bâillons (SLAPP): Rapport du comité au ministre de la Justice (Ministère de la Justice du Québec, 2007), at 94.

${ }^{32}$ The very notion of strategic lawsuits against public participation remains context-contingent and is deeply influenced by the political and legal settings of the jurisdiction in which abusive prosecutions take place. See Macdonald et al. at n. 5 above, at 2-9.

${ }^{33}$ See Macdonald, et al., ibid., at 6.
} 
This definition became consensual and was later adopted by the vast majority of public interveners on SLAPPs. ${ }^{34}$ The central role played by the report in the subsequent public hearings on SLAPPs (see below) came from its use as a tool for political lobbying by a number of groups and citizens trying to convince the legislator to adopt anti-SLAPP legislation. The conclusions of the report were indeed largely supportive of legislative action. The report stated that:

The resort to strategic lawsuits against public participation ${ }^{35}$ is a real phenomenon, although it does not undergo systematic practice in Quebec. Cases recently highlighted by the media however, reveal that SLAPPs are an observable reality and constitute a genuine threat to citizens and groups' participation in public debates. In this particular sense, it is both a threat to participatory democracy and represents a real risk of diverting the purposes of justice. For this reason, it is necessary to intervene so that these practices are discouraged. More specifically, it appears imperative to the members of this committee that any policy regarding the management of these practices meet the following objectives:

1) the protection of the right to freedom of expression and opinion;

2) the swift interruption of SLAPP lawsuits in courts;

3) the deterrence of the initiators of a SLAPP;

4) maintaining the integrity and purpose of the judiciary;

5) access to justice. ${ }^{36}$ (Translation by the author)

In order to accomplish these goals, the authors of the report proposed the following:

1. that a normative definition of SLAPPs be established;

2. that a mechanism for an accelerated legal procedure be installed;

3. that the costs and court costs of victims of SLAPPs be reimbursed;

4. that the capacity of the judge to play an active role in the handling of SLAPPs be enhanced and clarified;

5. that financial resources or professional assistance be provided to victims of SLAPPs; and

6. that punitive or exemplary damages be imposed over those who resort to strategies of legal intimidation. ${ }^{37}$ (Translation by the author)

The authors identified three options for the legislature to choose from in order to enforce the above-mentioned remedies and further argued against the importation of prefabricated solutions that might clash or be inadequate with Quebec's legal culture and tradition. ${ }^{38}$ These three options were the following:

- the enactment of a specific anti-SLAPP law built around the models considered elsewhere in Canada and in the United States establishing substantive rights and a special procedure;

\footnotetext{
${ }^{34}$ The reader might notice that the definition focuses on the intentions of the plaintiff and avoids qualifying SLAPPs as meritless actions.

${ }^{35}$ The original French version of the report uses the notions of 'poursuites stratégiques contre la mobilization publique' (strategic lawsuits against public participation) and 'poursuites-bâillons' (gagging lawsuit) as synonyms. For the same of clarity, I will only use the first of these terms in the present article.

${ }^{36}$ See Macdonald, et al. n. 5 above, at 76.

${ }^{37}$ Ibid.

${ }^{38}$ According to Macdonald, et al., the distinct nature of Quebec's judicial system called for specific antiSLAPP measures. Indeed, Quebec remains the only Canadian province of civil law tradition and has its own provincial Charter of Human Rights and Freedoms. See Macdonald, et al. n. 5 above, at 44-45.
} 
- the amendment to the Code of Civil Procedure with the creation of a fund dedicated at supporting SLAPP victims; and,

- the adoption of the previous option but as part of legislation dedicated to the protection of the courts from the misuse of the judicial function, to the promotion citizen participation in public debate and to the exercise of citizens' rights to freedom of expression and opinion.

These three options served as the basis for subsequent political discussions over the feasibility and desirability to adopt anti-SLAPP legislation in Quebec.

\section{Convincing the Legislator: the Life and Death of Bill 99}

The Macdonald Report gave credibility and legitimacy to the public demands for the enactment of anti-SLAPP legislation. As time passed, concern started to rise among civil society groups that it would be shelved and soon forgotten. This was not to be the case. Nine months after the transmission of the report to the Minister of Justice, the National Assembly mandated the Commission of the Institutions to hold, simultaneously, public hearings on the Macdonald Report and on the Reform of the Code of Civil Procedure.

These hearings were held from February to April 2009. Thirty-seven groups from all over the province contributed to the process. The vast majority of these groups spoke about SLAPPs and all but one of these groups expressed support for the introduction of antiSLAPP legislation in Quebec. ${ }^{39}$ Various groups used the hearings as a platform to generate media coverage on the issue, to get organized and to lobby political parties. The public hearings were also instrumental in building a larger coalition of organizations that took the leadership of building a sustained and enlarged campaign of political lobbying and pressurizing the legislature to adopt anti-SLAPP legislation without further delay. ${ }^{40}$

These actions proved to be fruitful. On June 13, 2008, the Minister of Justice presented the first anti-SLAPP bill to the National Assembly. Bill 99 consecrated of the third option

\footnotetext{
${ }^{39}$ Interestingly, the only intervenor who expressed reservations over the enactment of anti-SLAPP legislation at that time was Quebec's Bar. According to the Bar Association, the number of alleged SLAPP cases found in the province did not justify the enactment of a new legislation. The Bar also called for further study of the situation before taking legislative action. See K. Dougherty. 'Don't push for antiSLAPP law, Bar urges justice minister', The Gazette (21 February 2008), at A.9.

${ }^{40}$ The coalition was composed of primarily two environmental organizations (the Association québécoise de lute contre la pollution atmosphérique and the Réseau québécois des groupes écologistes), a human rights group (the Ligue des droits et libertés) and later by Les Éditions Écosociété, a small non-profit publishing company, which was sued for CAD\$11 million by two major Canadian mining corporations. In April 2008, Écosociété and the three authors of the book Noir Canada: Pillage, corruption et criminalité en Afrique (A. Deneault et al., Écosociété, 2008) sued by the giant Canadian mining firm Barrick Gold for CAD \$6 million. This action was followed in May 2008 by a CAD \$5 million lawsuit from Banro Corporation. Both firms allege that the book contains false, libelous and defamatory statements while Écosociété claims that 'Noir Canada brings together and analyses national and international documents already available to the public (reports, books, documentaries...), concerning various abuses from several Canadian companies working in Africa, in particular in the mining and oil areas.' Solidarity with Écosociété Website (Écosociété, undated) <http://slapp.ecosociete.org/en/node/71>. Barrick's demand letter is available online on the Écosociété Solidarity website at $<\mathrm{http}$ ://www.ecosociete.org/t117Mise_en_d_Barrick.PDF>.
} 
put forward by the Macdonald Report as the definitive avenue selected by the legislature to address SLAPP suits. As such, Bill 99 was explicit in its need to prevent abusive use of the courts, as well as to promote freedom of expression and citizen participation in public debate. The bill also contained explanatory notes and a preamble that clarified the intentions of the legislature in enacting it. Bill 99 was to amend 'the Code of Civil Procedure to promote freedom of expression and prevent abusive use of the courts, in particular the use of court proceedings to thwart the right of citizens to participate in public debate'.

These measures were adopted in order to:

- promote freedom of expression as affirmed in the Charter of human rights and freedoms;

- prevent abusive use of the courts and discourage judicial proceedings designed to thwart the right of citizens to participate in public debate and to;

- promote access to justice for all citizens and to strike a fairer balance between the financial strength of the parties to a legal action.

While the bill was deeply influenced by the Macdonald Report, it diverged from it in two specific ways. The report first argued for the insertion of amendments to Articles 75.1 and 75.2 of the Code of Civil Procedure and for the addition of a new paragraph in Article 165. ${ }^{41}$ The bill instead repealed Articles 75.1 and 75.2, modified article 165 and inserted new articles (54.1 to 54.6) under Section III, Power to Impose Sanction for Improper Use of Procedure. ${ }^{42}$ The legislature found that it would be more effective to proceed by applying these changes instead of those proposed by the Macdonald Report. This alternative legislative route taken by Bill 99 was well received by the authors of the report who felt that is was congruent with their goals and proposals. ${ }^{43}$ The report further argued for the establishment of a public fund dedicated to providing financial assistance to potential victims of SLAPP suits. This idea was met with 'hesitation' and 'resistance' on the part of the Minister of Justice and was not inserted in the bill. ${ }^{44}$

\footnotetext{
${ }^{41}$ Article 75.1 previously allowed the Court to dismiss an action or proceeding found to be frivolous or clearly unfounded. Article 75.2 further allowed the court to declare improper or dilatory an action or proceeding dismissed under 75.1 and order the losing party to pay damages to its adversary. Finally, article 165 (4) provided the defendant with the right to request the dismissal of an action unfounded in law, even if the facts alleged were true. Highly restrictive interpretations of these provisions by successive court decisions pushed the authors of the Macdonald Report to conclude that 'they are of very limited use if the objective is to counter SLAPP attempts at the outset of proceedings.' (Translation by the author). See Macdonald et al., n.5 above, at 57. See also V. Pelletier, Strategic Lawsuits against Public Participation (SLAPPS) (and other abusive lawsuits) (Uniform Law Conference of Canada (ULCC), Civil Section, August 2008), available at $<$ http://www.environmentaldefence.ca/campaigns/pdf/UniformLawConfSLAPP\%20Report.pdf>.

42 The final draft of the bill will avoid making change to article 165 .

43 While discussing the bill with members of the Commission des Institutions at the National Assembly, Professor Pierre Noreau expressed his general satisfaction with it and declared 'that overall it corresponds very much to what we indented to propose' (Translation by the author). Transcriptions of the 'Special consultations on Bill No. 99 - An Act to amend the Code of Civil Procedure to Prevent Improper Use of the Courts and Promote Freedom of Expression and Citizen Participation in Public Debate' 43 :62 Journal des débats. (Quebec National Assembly, 14 October 2008).

44 This will be discussed more in details below. J. Dupuis, 'Consultation générale sur les documents intitulés Rapport d'évaluation de la Loi portant réforme du Code de procédure civile et Les poursuite
} 
Particular consultations on Bill 99 were announced later in the summer of 2008 and were held later in October of that year. Thirty-one groups were invited to contribute to the exchange with elected representatives regarding the merits and weaknesses of the bill. The process went smoothly and the Minister of Justice was confident that an improved bill could be adopted before the end of the year. Yet politics got the upper hand over the bill; the Liberal government, hoping to seize a majority of seats in National Assembly, dissolved the chamber and announced general elections in November 2008. Bill 99 died on the order paper while it was still at an early stage. While the Liberal Party won the election and even obtained a majority in the National Assembly, many feared that the elections would bury the legislative initiative under new and more politically attractive priorities.

Members of the anti-SLAPP coalition lobbied the new Minister of Justice extensively in the months that followed the elections, requesting the resurrection of an improved, more adequate anti-SLAPP bill. These efforts proved to be successful. On April 7, 2009 a newly drafted anti-SLAPP bill - Bill 9, keeping the same title as the previous version was presented to the National Assembly. The Bill received strong support from opposition parties and became law two months later.

\section{An Act to Amend the Code of Civil Procedure to Prevent Improper Use of the Courts and Promote Freedom of Expression and Citizen Participation in Public Debate: Dissecting Bill 9}

Quebec's anti-SLAPP legislation remains a unique experiment in Canada in at least two ways. First, it does not enter the field of substantive law and avoids both the creation of new rights and obligations and the modification of existing laws. SLAPPs are understood by the legislation as the expression of the judicial system's failure to deal adequately with abusive prosecutions and abuse of process. Consequently, it is built upon the conviction that what is needed in order to address the issue is a reform of the rules of legal proceedings leading to tougher, stronger, and more robust procedural provisions on abusive lawsuits and proceedings. The remedies to SLAPP suits brought by the law are therefore strictly procedural. ${ }^{45}$

As contradictory as it might first appear, Quebec's anti-SLAPP legislation also does not address SLAPP suits per se. The real focus of the law is not so much on strategic lawsuits against public participation - though the concept remains an important element

stratégiques contre la mobilisation publique - les poursuites-bâillons (SLAPP)' 40 :28 Journal des débats (Quebec National Assembly. 26 February 2008).

${ }^{45}$ The choice of acting legislatively on SLAPPs from this precise perspective also followed an evaluation of the legal difficulties that would have arisen from the elaboration of legislation entering substantive law. According to Macdonald et al., such legislation would result in 'hand-picked changes into quasiconstitutional laws' and would eventually require the insertion of a 'Right to public participation' in the Quebec Charter of Human rights and Freedoms. Macdonald et al. n.5 above, at 77. The Minister of Justice, Jacques Dupuis, qualified this option as the 'Big Bertha' of anti-SLAPP solutions - highlighting its heaviness and complexity. See See J. Dupuis, n. 43 above. 
of the legislation and the driver behind its enactment - than on the larger notion of 'improper proceeding', which ...

... may consist in a claim or pleading that is clearly unfounded, frivolous or dilatory or in conduct that is vexatious or quarrelsome. It may also consist in bad faith, in a use of procedure that is excessive or unreasonable or causes prejudice to another person, or in an attempt to defeat the ends of justice, in particular if it restricts freedom of expression in public debate. (Quebec Code of Civil Procedure (C.P.C). Art. 54.1, second paragraph) [Emphasis by the author]

While the legislation's central concept of improper proceeding focuses on attempts to defeat the ends of justice in ways that restrict freedom of expression in public debate $-\mathrm{a}$ central attribute of SLAPPs - it is by no means restricted to this. This is a major difference with other previous Canadian anti-SLAPP legislative attempts. The scope of action of these bills remained limited to legal actions and proceedings that were instigated as a result of a type of public participation from the defendant, aiming to weaken this participation (or to retaliate against it for having done so). Quebec's law broadens its range of application to reprehensible legal practices that might not have any relation to citizen participation in public debate.

This clarification having been made, there are a number of measures contained in the legislation that have strong applications for countering strategic lawsuits against public participation. These provisions are the based on the following:

1. the possibility for the court to dismiss improper proceedings;

2. the reversal of the burden of proof in favour of the defendant;

3. the attribution of more adequate powers to the courts for handling more closely proceedings that appears to be improper;

4. the attribution of a provision for the costs to the defendant;

5. the condemnation of parties who abused the courts to pay costs and damages to the defendant; and

6. the personal condemnation of directors and officers who took part in decisions to instigate improper proceedings.

The following sub-sections will present and discuss the various provisions of Quebec's new law and address some of the concerns surrounding it.

\section{The Provisions}

The legislation first confers the power to the courts to declare 'at any time, on request or even on its own initiative after having heard the parties on the point', 'an action or other pleading improper and impose a sanction on the party concerned' (Article 54.1). In the event that a court finds that a pleading or action constitutes an improper use of procedure, it may 'dismiss the action or other pleading, strike out a submission or require that it be amended, terminate or refuse to allow an examination, or annul a writ of summons served on a witness' (Article 54.3. This grants the court the power to follow closely the proceedings and to intervene more rigorously when required in order to ensure the proper proceeding of the case. Furthermore, the new legislation provides the court with an 
extensive set of powers to be used with discretion where it only appears that a proceeding may be improper. If considered appropriate, the court may:

- subject the furtherance of the action or the pleading to certain conditions;

- require undertakings from the party concerned with regard to the orderly conduct of the proceeding;

- $\quad$ suspend the proceeding for any period of time that it deems appropriate;

- recommend to the chief judge or chief justice that special case management be ordered; or

- order the initiator of the action or pleading to pay to the other party, under pain of dismissal of the action or pleading, a provision for the costs of the proceeding, if justified by the circumstances and if the court notes that without such assistance the party's financial situation would prevent it from effectively arguing its case (Article 54.3).

The first four above-mentioned measures are aimed at providing the court with the tools to get a much more solid handling over actions and proceedings that appear to be abusive, unjustified or wasteful. The fifth and final paragraph of Article 54.3 is one of the most important elements of the law as it is dedicated to providing financial assistance to potential victims of improper use of procedure. Groups and citizens in favour of the enactment of anti-SLAPP legislation lobbied extensively over the need to provide victims of SLAPPs with some form of financial assistance. While the majority of these groups supported the creation of a State-sponsored fund dedicated at providing this assistance, the idea was not favourably received by the legislature. It was decided that is was preferable to establish a procedure through which a party which appears to have used the legal procedure in an improper way could be constrained to finance in part or in whole its adversary's defence. We will see below that this solution could be problematic.

The law further facilitates the reversal of the burden of proof in favour of the defendant. This is a crucial element of any efficient anti-SLAPP legislation as it shifts the onus away from victims of abusive prosecutions to SLAPPers and reverses the offensive-defensive dynamics between parties. Yet the effectiveness of the measure largely depends on the actual capacity of SLAPP victims to successfully request it from the court. Article 54.2 states that:

If a party summarily establishes that an action or pleading may be an improper use of procedure, the onus is on the initiator of the action or pleading to show that it is not excessive or unreasonable and is justified in law.

The requirements to obtain the reversal of the burden of the proof are quite minimal: the defendant only has to demonstrate to the court that the action or pleading intended against him may be an improper use of procedure to compel his adversary in a defensive position. This precise provision was designed to be easily accessible to potential victims of improper proceedings.

Quebec's legislation also grants the court with the power to condemn the parties that instigated an improper action or pleading to pay costs - including fees and extrajudicial costs - and punitive damages, 'if justified by the circumstances', to the victims of such 
improper actions (Article 54.4). This is typical of anti-SLAPP legislation. ${ }^{46}$ Yet Quebec's legislation went a step further and allows courts to sanction personally the directors and officers of a legal person who committed an improper use of procedure:

54.6. If a legal person or an administrator of the property of another resorts to an improper use of procedure, the directors and officers of the legal person who took part in the decision or the administrator may be ordered personally to pay damages.

This appears to be unique to Quebec's legislation. It aims at breaking the legal cover under which directors and administrators of legal entities - and of corporations in particular - hide while using the judicial system as a tool for political and economic intimidation. This provision inserts a significant level of (personal) risk for those who might be tempted to abuse the judicial system in order to achieve extrajudicial goals. This language was heavily criticized by representatives of the business community when discussed at the October 2008 public hearings, arguing that the measure was 'totally disproportional', 'unfair', that it would constitute a 'burden' for the investors, business people and administrators of the province and further present itself as a disincentive for foreign investments. ${ }^{47}$ The Minister of Justice disagreed with these interpretations. He argued that the bill was 'measured' and further expressed his belief in the utility of the provision as a disincentive to abusive lawsuits. ${ }^{48}$

Taken together the above-mentioned provisions constitute the general anti-SLAPP framework developed by the legislation adopted by the National Assembly. Yet the fundamental question remains: will these constitute an effective legal framework to counter strategic lawsuits against public participation? In order to answer this question, I argue that any efficient anti-SLAPP legislation must essentially do three things:

- $\quad$ rotect citizens and the judiciary from abusive lawsuits ;

- dissuade potential SLAPPers from resorting to strategies of legal intimidation; and

- adequately compensate SLAPP victims.

\footnotetext{
${ }^{46}$ See The Protection of Public Participation Act, SBC 2001 ch. 19, Article 5(2)(b): 'The court may, in addition to the orders referred to in paragraph (a), on its own motion or on the application of the defendant, award punitive or exemplary damages against the plaintiff.' . See also Minnesota Chapter 554: Free Speech; Participation in Government, Section 554.04, Fees and Damages (Subd. 2.(b)) which states: '(b) If a motion under this chapter is granted and the moving party demonstrates that the respondent brought the cause of action in the underlying lawsuit for the purpose of harassment, to inhibit the moving party's public participation, to interfere with the moving party's exercise of protected constitutional rights, or otherwise wrongfully injure the moving party, the court shall award the moving party actual damages. The court may award the moving party punitive damages under section 549.20. A motion to amend the pleadings under section 529.191 is not required under this section, but the claim for punitive damages must meet all other requirements of section 549.191.'

${ }^{47}$ D. Audet, on behalf of the Conseil du Patronat du Québec, 'Transcriptions of the 'Special Consultations on Bill No. 99 - An Act to Amend the Code of Civil Procedure to Prevent Improper Use of the Courts and Promote Freedom of Expression and Citizen Participation in Public Debate' 43:62 Journal des débats. (Quebec National Assembly. 14 October 2008).

${ }^{48}$ J. Dupuis, 'Transcriptions of the 'Special Consultations on Bill No. 99 - An Act to Amend the Code of Civil Procedure to Prevent Improper Use of the Courts and Promote Freedom of Expression and Citizen Participation in Public Debate' 43: 62 Journal des débats. (Quebec National Assembly. 14 October 2008).
} 
We will see that while the new legislation offers some interesting features, it also falls short in some important respects.

\section{Bill 9: A Preliminary Evaluation}

The protection of citizens and of the legal system from SLAPPs requires three fundamental elements: first, the rapid dismissal of abusive claims, then the existence of provisions that will both simplify and lighten the organization of the defence for SLAPP victims, and finally provision of financial assistance for citizens targeted by SLAPP suits.

As it stands now, there is little chance that the new legislation will provide the courts with the incentive to quickly dismiss actions or proceedings that are not clearly improper. There is a strong legal tradition in Quebec of carefulness in rejecting actions that might or could be improper; such a dismissal could interfere with the plaintiff's right to seek redress in court. Therefore there is a risk that only actions or proceedings that appear clearly improper can be summarily dismissed by the courts. This could be highly problematic. Many SLAPPs emerge from complex issues and do not present themselves as openly improper actions. They rely on maintaining some appearance of legitimacy before the courts. It might become impossible for the defendant to obtain the dismissal of more sophisticated SLAPPs. One might also argue that the law does not properly address the question of legal delays. SLAPPs bring to their victims tremendous psychological and financial pressures as they are often kept in the judicial sphere for years. While expressing its view over awarding attorneys' fees and expenses in SLAPP cases, the New York Supreme Court stated that:

The longer the litigation can be stretched out, the more litigation can be churned, the greater the expense that is inflicted, the closer the SLAPP filer moves to success ... The ripple effect of such suits in our society is enormous. Persons who have been outspoken on issues of public importance targeted in such suits or who have witnessed such suits will often choose in the future to stay silent. ${ }^{49}$

These are serious disincentives to public participation. In order to avoid such 'ripple effect', a number of American pieces of anti-SLAPP legislation have established provisions that would ensure that motions requesting the dismissal of illegitimate actions be heard by the court without too much delay. ${ }^{50}$ Quebec's legislation does not contain such provisions. The law compensates for its limited capacity in by providing more powers to the courts to respond more adequately to pleadings and proceedings that appear to be improper. As such, it sends a signal to the judicial authorities that they are expected to closely monitor the actions presented before them and that they are to ensure that these actions do not constitute attempts to abuse the judiciary or the defendants' rights. Quebec's legislation expresses a strong belief that the courts will use these new

\footnotetext{
${ }^{49}$ Gordon v. Marrone N.Y. Supreme Court, 1992 (590 N.Y.S.2d 649).

${ }^{50}$ California's anti-SLAPP statute is a good example of this. It specifies that actions subject to a special motion to strike under the law must be 'scheduled by the clerk of the court for a hearing not more than 30 days after the service of the motion unless the docket conditions of the court require a later hearing'. California Code of Civil Procedure, Claim Arising from Person's Exercise of Constitutional Right of Petition or Free Speech - Special Motion to Strike $\$ \oint 425.16$ - 425.18, Section 425.16. (f).
} 
provisions in a manner that is congruent with the objectives of the law. The extent to which this belief is founded in reality is yet to be established by the jurisprudence. ${ }^{51}$

There is little doubt that the new procedure organizing the reversal of the burden of the proof in favour of the defendant is a significant anti-SLAPP provision in the legislation. The financial protection it offers SLAPP victims appears to be more problematic. As a mechanism dedicated at relieving potential victims of improper proceedings, a provision for the costs is effective only to the extent to which it is made available to those who need it. Crucial to the efficiency of the mechanisms is the nature of the criteria to be met for the court to order it. The legislation establishes three - two of them being quite vague criteria to be met in order for the court to allocate the provision for costs to the defendant. The court must first be convinced that there is at least an appearance of improper use of procedure by the plaintiff. It must then decide if the circumstances justify the attribution of the provision for the costs. The court must finally decide if the absence of financial assistance would impair the defendant's capacity to effectively argue its case. There are no indications in the legislation regarding what would constitute 'proper circumstances' for it to order the provisions for the costs. ${ }^{52}$ There is also no further clarification on what would constitute a situation in which party's financial situation 'would prevent it from effectively arguing its case' (Article 54.3. (5)). The notion of effectiveness implied here is especially problematic and could be interpreted in numerous ways by the courts.

Furthermore, both Quebec and Canadian courts have been reluctant in the past to grant defending parties with a provision for the costs and have applied strict principles that ought to justify its attribution. ${ }^{53}$ And while the Minister of Justice was clear that the law was to send a message that the courts would need to depart from this restrictive approach, ${ }^{54}$ it remains to be seen if the judicial authorities will actually apply other, less restrictive guidelines in deciding when and how to order the provision for the cost from the initiator of an action.

\footnotetext{
${ }^{51}$ No judgment has been given by the courts on alleged SLAPP cases since the adoption of the law. This situation is likely to change in the near future. Écosociété and the three authors of Noir Canada publicly state that they 'will soon make use of the new legislative tools at their disposal' and that they intend to make of their case 'an efficiency test for this new legislation'. See 'Adoption of Bill 9: Écosociété and the authors of Noir Canada will be the test' Solidarity with Écosociété Website (undated), available at $<$ http://slapp.ecosociete.org/en/node/16077>

52 That said, the Minister of Justice gave strong indications that the existence of considerable financial disparities between the parties could become a criterion to justify the attribution of a provision for the costs by the courts. This measure would then be used by the courts to rebalance the financial means of the parties. See K. Weil, 'Étude détaillée du projet de loi $\mathrm{n}^{\circ} 9$ - Loi modifiant le Code de procédure civile pour prévenir l'utilisation abusive des tribunaux et favoriser le respect de la liberté d'expression et la participation des citoyens débats publics' 41:16, Journal des débats. (Quebec National Assembly. 26 May 2009).

${ }^{53}$ V. Pelletier, Strategic Lawsuits against Public Participation (SLAPPs) (and other abusive lawsuits), (Uniform Law Conference of Canada (ULCC), Civil Section, Quebec City, August 2008), available at $<$ http://www.environmentaldefence.ca/campaigns/pdf/UniformLawConfSLAPP\%20Report.pdf>.

${ }^{54}$ This argument follows the analysis of the detailed study of Bill 9 by members of the 'Commission des institutions’ on 26 May 2009. See 41:16 Journal des débats. (Quebec National Assembly, May 26, 2009).
} 
Dissuasive and compensatory measures are often closely related in anti-SLAPP legislation as they both rely on the penalization of parties that brought or maintained abusive actions before the court. On paper, Quebec's new law has teeth and could constitute a proper disincentive for potential SLAPPers to resort to strategies of legal intimidation. The opening towards the personal penalization of administrators and directors who instigate improper proceedings under the name of a legal entity is a significant attribute of the legislation. In this respect, Quebec's legislation compares admirably with others anti-SLAPP statutes. The legislation opens the door for SLAPP victims to seek damages from improper proceedings and relaxes the strictness of the attribution process. In the end, SLAPP victims ought to be compensated for their financial losses, wasted hours and the psychological trauma resulting from these lawsuits. This was unlikely to happen in the province prior to the enactment of the legislation. As Macdonald argued in his report, the reimbursement of legal costs - including those of legal representation - could be imposed on the losing party only in exceptional cases. ${ }^{55}$ The new compensatory measures inserted in the Code of Civil Procedure ought to change this. Yet again, the new dissuasive and compensative provisions inserted in the law at Articles 54.4 and 54.6 will be significantly set by the jurisprudence. Restrictive judicial applications of these provisions would considerably weaken their preventive and punitive functions.

\section{Conclusion}

The enactment of anti-SLAPP legislation is not only a legislative act. It is also a communicative gesture sending a strong message to various stakeholders that the legislative and judicial authorities are aware of the existence of these abusive lawsuits and that they are not to be tolerated. The best anti-SLAPP legislation acts preventatively and discourages strategies of legal intimidation upstream. The issue now is to find out the extent to which Quebec's anti-SLAPP legislation will accomplish this. This piece of legislation is by no means perfect. It lacks some important features and is restrained by a legal tradition unsympathetic to the active involvement of the courts in legal proceedings and to the dismissal of (later to be proven) improper legal actions. ${ }^{56}$ Yet it does have many interesting features and could constitute a real and significant improvement of the level of legal protection from abusive prosecution enjoyed by the citizens of the province. Much of the new legislation's effectiveness will depend on the jurisprudence to be established by Quebec courts in SLAPPs-related cases.

A number of troubling legal cases will be heard by Quebec's Superior Court in the upcoming months. ${ }^{57}$ These cases will be of tremendous importance for the new law. In the end, much of the worth of three years of sustained political lobbying and campaigning and endless phones calls and meetings with elected representatives will depend on

\footnotetext{
${ }_{55}^{55}$ See Macdonald et al. n. 5 above, at 64.

${ }^{56}$ See V. Pelletier, n.40 above and Macdonald et al. n. 5 above.

${ }^{57}$ See the Écosociété's legal case at n. 40 above. See also the Serge the Galipeau and Christine Landry's legal case at n. 30 above. Citizens and groups lobbied extensively the Minister of Justice to ensure that the upcoming legislation would apply to pending cases. See L-G. Francoeur, 'Poursuites abusives: la loi québécoise s'étendra aux causes pendantes.' Le Devoir. 8 April 2009.
} 
whether the courts will apply broadly or restrictively the new provisions inserted in the Code of Civil Procedure. Indeed, citizen groups and organizations feared that conservative legal decisions might jeopardize the effectiveness of the legislation and convinced the legislature to insert a provision in the final draft of the bill requesting the Minister of Justice to present a report on the application of the legislation by the courts to the National Assembly. This report will have to be submitted to the legislature no later than 1 October 2012 and could provide an opportunity to correct any unsatisfactory applications of the new anti-SLAPP provisions by the judicial authorities. These upcoming developments will be closely followed and monitored by civil society organizations and dedicated legal experts. While the adoption of Bill 9 opened possibilities for citizens to respond to abusive prosecution, it is still too soon to claim that the battle against strategic lawsuits against public participation has been won in Quebec.

Normand Landry is a PhD Candidate in the Department of Art History and Communication Studies at McGill University where he holds a SSHRC Canada Graduate Scholarship (CGS). Before coming to McGill he was affiliated with the Communication Policy Research Laboratory (LRPC) at Universite de Montréal, where his work on global media governance and the World Summit on the Information Society was published, with Marc Raboy, as Civil Society, Communication, and Global Governance (Peter Lang Publishers). Normand was heavily involved in Quebec's anti-SLAPP movement and is now a researcher at the Media@McGill unit for critical communications research. His current work focuses on social movement theory, law and democratic communications. 